\title{
Traditional medicinal uses of the Eurasian wild grapevine in the Iberian Peninsula
}

\author{
Carlos A. OCETE ${ }^{1}$, Rafael F. OCETE 2 , Rafael OCETE ${ }^{3}$, Miguel LARA ${ }^{4}$, Gustavo RENOBALES 5 , \\ José Manuel VALLE ${ }^{6}$, Álvaro RODRÍGUEZ-MIRANDA ${ }^{7} \&$ Ramón MORALES $^{8 *}$ \\ ${ }^{1,3}$ Freelance, La Gualdia 9, 26211 Tirgo, La Rioja, Spain. \\ ${ }^{2} \mathrm{SAS}$, Hospital Universitario Virgen del Rocío, Av. Manuel Siurot, s/n, 41013 Sevilla, Spain. \\ ${ }^{3}$ Centro IFAPA Rancho la Merced, Carretera Cañada de la Loba (CA-3102) PK 3,1, Apartado de Correos 589, Jerez de la Frontera, Spain. \\ ${ }^{4}$ Editorial Libros del Jata, Alameda Recalde 27, Piso 1, 48009 Bilbao, Spain. \\ ${ }_{5,6,7}$ Laboratorio de Documentación Geométrica del Patrimonio (UPV/EHU), C/ Justo Vélez de Elorriaga 1, 01006, Vitoria-Gasteiz, Spain. \\ ${ }^{8}$ Real Jardín Botánico, CSIC, Plaza de Murillo 2, 28014 Madrid, Spain. \\ *Correspondence: rmnmvtp@gmail.com \\ ${ }^{1}$ https://orcid.org/0000-0002-2660-9485, ${ }^{2}$ https://orcid.org/0000-0002-8432-3637 \\ ${ }^{3}$ https://orcid.org/0000-0003-3289-4224, ${ }^{4}$ https://orcid.org/0000-0002-8756-8816 \\ ${ }^{5} \mathrm{https}: / /$ orcid.org/0000-0002-6051-2070, ${ }^{6} \mathrm{https}: / /$ orcid.org/0000-0001-6981-0886 \\ ${ }^{7}$ https://orcid.org/0000-0002-6961-5543, ${ }^{8}$ https://orcid.org/0000-0003-2343-9158
}

\begin{abstract}
The Iberian Peninsula constitutes the Western limit of the dioecious Eurasian wild grapevine (Vitis vinifera L. subsp. sylvestris). At present, it is a threatened plant, due to human impacts. This liana has had different uses in this territory from the Paleolithic until the end of the last century, including several medicinal applications, inherited from the classical Greek culture. In order to retrieve the available written information, we carried out an exhaustive bibliographic search of the pharmacopoeia linked to this Vitaceae, from the $16^{\text {th }}$ century to the present day. Current references on chemical composition of different parts of grapevine and their medicinal uses were also covered. In parallel, we conducted research in several archives and made inquiries to historians, anthropologists, and sanitary personnel. We also interviewed elderly people from rural areas of Spain and Portugal where some relic populations of wild grapevine are still conserved. Among the written and oral medicinal uses compiled, the main ones are: the use of the grapevine bleeding water to alleviate eczema and skin eruptions and to combat conjunctivitis and keratitis; the use of must from unripe berries (agua de agraz in Spanish) as liver tonic and to treat digestive diseases; the leaves were used to reduce edema, as antihemorrhoidal, and for menopausal disorders and finally, the vinegar was used to clean and disinfect wounds both on humans and animals. This paper highlights the tremendous erosion of the traditional knowledge about this relevant plant genetic resource.
\end{abstract}

Keywords. Bleeding water, leaves, must, vinegar, Vitis vinifera L. subsp. sylvestris.
Resumen. La Península Ibérica constituye el límite occidental de la euroasiática y dioica vid silvestre (Vitis vinifera L. subsp. sylvestris). Actualmente la vid silvestre se encuentra amenazada debido al impacto humano. Esta liana tuvo diferentes usos en la península desde el Paleolítico hasta finales del siglo pasado. Entre ellos, como herencia de la cultura griega clásica, aparecen diferentes usos médicos. Para recuperar la información escrita existente, hemos llevado a cabo una búsqueda bibliográfica exhaustiva sobre la farmacopea vinculada a esta Vitaceae, desde el siglo XVI hasta el presente. Incluimos también referencias sobre la composición química de diferentes partes de la vid y sus usos medicinales. Paralelamente, hemos investigado en los archivos de diferentes localidades y realizado consultas a historiadores, antropólogos y personal sanitario. Asimismo, hemos realizado entrevistas a ancianos de diferentes regiones de España y Portugal donde todavía se conservan algunas poblaciones relictas de vid silvestre. Entre la información escrita y oral de los usos medicinales recopilados, mencionaremos el uso del "agua de lloro" de la vid para aliviar eczemas y erupciones cutáneas; para combatir la conjuntivitis y la queratitis; el mosto o "agua de agraz", como tónico para el hígado y para tratar afecciones digestivas; las hojas para reducir el edema, como antihemorroidales y para trastornos de la menopausia; y por último, el vinagre para limpiar y desinfectar heridas de personas y animales. Este trabajo destaca la tremenda erosión del conocimiento tradicional sobre este recurso fitogenético tan relevante.

Palabras clave. Agua de 1loro, hojas, mosto, vinagre, Vitis vinifera subsp. sylvestris.

How to cite this article: Ocete C.A., Ocete R.F., Ocete R., Lara M., Renobales G., Valle J.M, Rodríguez-Miranda A. \& Morales R. 2020. Traditional medicinal uses of the Eurasian wild grapevine in the Iberian Peninsula. Anales del Jardin Botánico de Madrid 77: e102. https:/doi.org/10.3989/ ajbm. 2555

Título en español: Usos tradicionales de la vid silvestre euroasiática en la Península Ibérica.

Associate Editors: Manuel Pardo-de-Santayana \& María P. Martín. Received: 22 April 2020; accepted: 29 October 2020; published online: 4 January 2021. 


\section{INTRODUCTION}

From the Iberian Peninsula to Afghanistan (Hindu Kush mountain-range) and the African Maghreb areas, only one type of Eurasian wild grapevine is found in natural ecosystems, mainly in river-bank forests on colluvial deposits. Its scientific denomination is Vitis vinifera L. subsp. sylvestris (C.C. Gmelin) Beger \& Hegi (Morales \& Ocete 2015). It is a dioecious liana, climbing through its tendrils on bushes and trees of the accompanying vegetation (Figs. 1, 2). This subspecies constitutes the parent of the current vineyard cultivars, which are mostly hermaphrodites and belong to Vitis vinifera $\mathrm{L}$. subsp. vinifera $[=V$. vinifera subsp. sativa $\mathrm{DC}$. ex Hegi] (Morales \& Ocete 2015).

The cultivated vines have been selected by man since the Neolithic period from hermaphrodite specimens that appeared by mutation of the cited wild subspecies in natural habitats. Humans observed that hermaphrodite plants exhibited a higher level of fruit set, given their power of self-fertilization, than that of the female plants that needed the contribution of pollen grains from more or less distant male specimens. For this reason, branches of hermaphrodite vines were selected in order to carry out the first plantations outside natural habitats (Forni 2006, 2012).

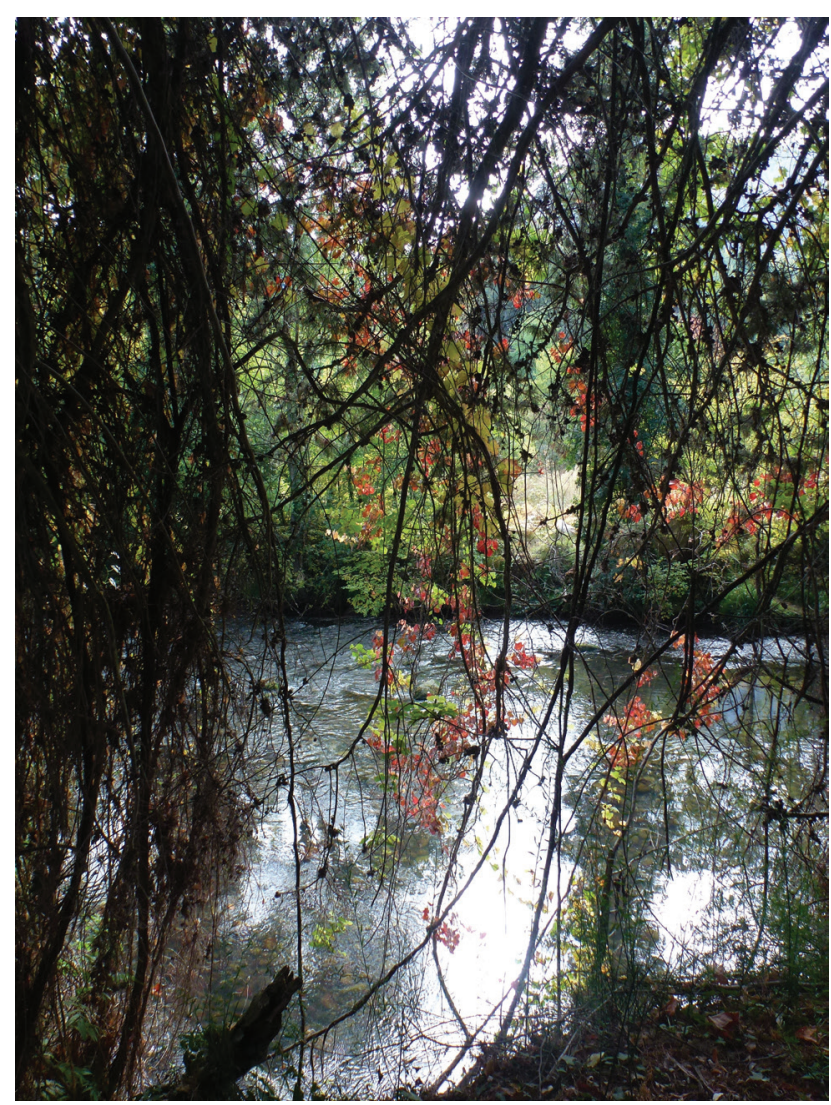

Fig. 1. Exemplar of wild grapevine (Vitis vinifera L. subsp. sylvestris) in a river-bank forest.
Seeds from wild female vines are morphologically different from cultivated ones, which are more elongated with longer peak. There are several morphometric indexes to distinguish both kind of pips, which were measured in archaeological sites, such as Stummer (1911), Logothetis (1974), Mangafa \& Kotsakis (1996), Terral \& al. (2010) and Orrù \& al. (2013).

The southern Caucasus constitutes the first and main focus of domestication and the cradle of the viticulture. Concretely in the site of Shulaveri Gora, Republic of Georgia, appeared the first domesticated seeds and ceramic vessels for must or wine, dated about 8000 years B.P. (McGovern 2003; Chilashvili 2004). During the quaternary glaciations, the Eurasian wild grapevine took refuge mainly in the aforementioned area of the Southern Caucasus ridge and also in some areas of the Mediterranean basin (Huglin 1986; Lehmann \& Böhm 2011).

In the case of the Iberian Peninsula, following the references included in Iriarte-Chiapusso \& al. (2013), fossils of grapevine pollen grains were found in Atapuerca site (Burgos) at the Trinchera Dolina level 7 (TD7). Their chronological ascription is located on the limit of the Lower and Middle Pleistocene (García-Antón 1989). They were also found in El Padul peat bog (Granada), located at the foot of the Sierra Nevada mountain-range, at levels of the

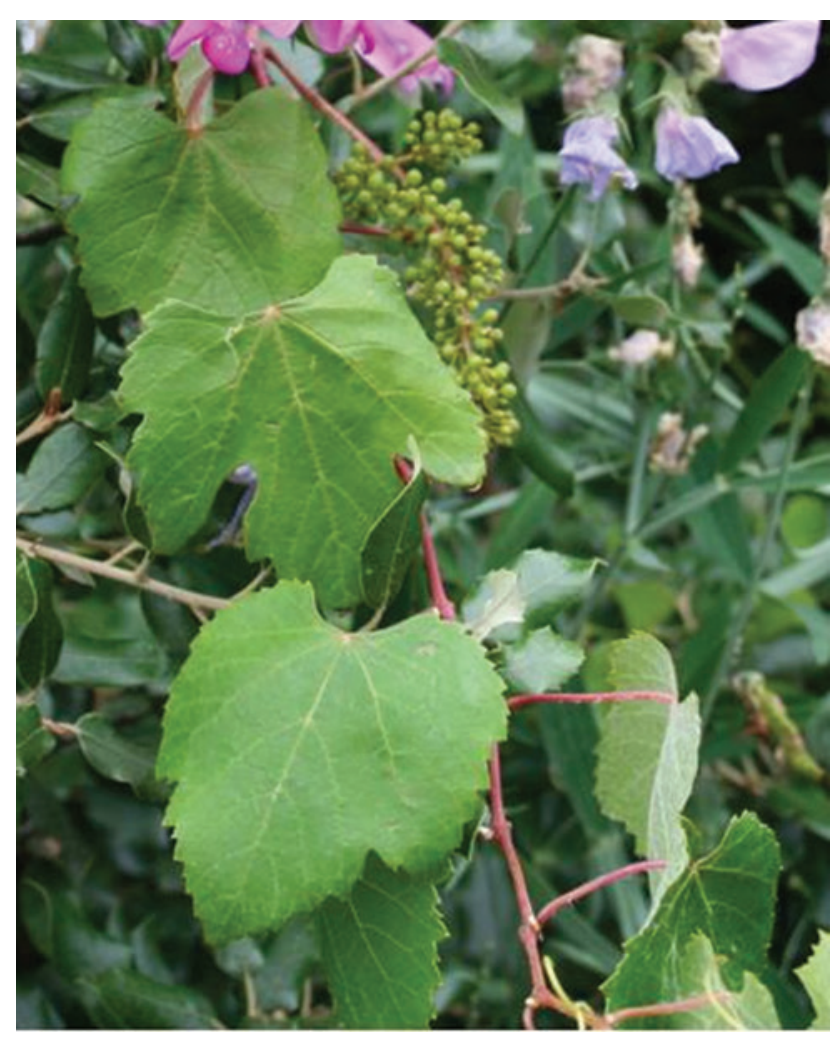

Fig. 2. Leaves of wild grapevine (Vitis vinifera L. subsp. sylvestris). The leaf base does not show a deep sinus as in subsp. vinifera. 
middle and upper Pleistocene (Florschütz \& al. 1971), as well as during the most recent phase of the Pleistocene. In the last glacial period (Würm), the wild vine was present in different peninsular areas, both in contexts inhabited by Neanderthals, Homo neanderthalensis, as in Abric Romaní (Barcelona) (Burjachs \& Juliá 1994) and, later, by Cro-Magnons, Homo sapiens, in Cova de les Malladetes (Valencia) (Dupré 1980).

In the Holocene, the presence of grapevine pollen is found both in the Basque country, within Biscay province (Iriarte-Chiapusso \& al. 2004), and in Andalusia, in the Laguna de Las Madres, Huelva (Stevenson 1985). It should be noted that these two locations are very close to certain current relic populations of wild grapevine which are conserved in both geographic protected areas: Urdaibai Biosphere Reserve, Basque country and Doñana National Park, Andalusia. Berries were used as human food at various periods, from the Paleolithic (Rivera \& Walker 1989) up to the last Spanish civil postwar, after 1939 (Ocete \& al. 2007).

The presence of seeds of wild grapes is frequent in burials ranging from the Bronze Age in the Argaric Culture of eastern Andalusia to the Early Christian period of the capital of Roman Lusitania, Mérida (Hopf 1961; TorresVila \& Mosquera Müller 2004).

The wild grapevine was called labrusca by Virgilius ( $1^{\text {st }}$ century), a voice that has been preserved in Romance languages such as Spanish, Portuguese, and Italian, whereas the similar word labrusque prevealed in French. In Spain, the plant is popularly known as vid silvestre in the majority of the regions, but other local names are also used. In Andalusia, it is known as parrón bravio or parrón moruno; in Montes de Toledo as parreña (Blanco 2002); in Extremadura as parra soteña (Blanco \& Cuadrado 2000), and it is known as uvas soteñas in Albacete (Verde \& al. 1998: 342). In the Basque country the names uvillas, zozo mahatsa and basamahatsondoa are used. Whereas in Catalonia, it is known as llambrusca, parra llambrusquera and vinya (Morales \& Ocete 2015). Clemente y Rubio (1807, 1879) gave two different names to both wild types of grapevine growing in La Algaida, a natural habitat situated between the town of Sanlúcar de Barrameda and the mouth of the Guadalquivir river (Cádiz, Andalusia). One of them was virgiliana, dedicated to the memory of Virgil (Fig. 3) and the other was garabatona, derived from garabato, a word from Arab origin (scribble in English), due to the high sinuosity of the leaf margin (Fig. 4). In the Sierra de Cazorla (Jaén), the parra silvestre has also the name of parra garabateña, which agrees with the name that Clemente employed 200 years ago (Fernández Ocaña 2000: 384). Finally, in Portugal it is known as videira brava, videira selvagem and parreira.
The little berries of the wild bunches used to be collected and eaten, at least in Sierra de Cazorla, Jaén, the Siberia region of Extremadura and in the Montes de Toledo (Fernández Ocaña 2000; Blanco \& Cuadrado 2000; Blanco 2002). Morevover, wild grapes have been used as wine additives. Quer \& Gómez Ortega (1784) indicated that wild grapes and flowers were used as preservatives of the wine made with cultivated grapes. They wrote: "The berries from wild grapevine have an astringent metallic flavor, these ones and male flower bunches are usually mixed with the must to communicate a longer duration to the wine, and a certain rasping flavor, pleasant to the taste and conforting to the stomach". Wines of that age, without the addition of potassium metabisulphite used today, with a possible high volatile acidity, were camouflaged to cause a pleasant stomach sensation. Male flowers (Fig. 5), which have a very pleasant smell, gave to the wine a fruity aroma. This procedure was also used in Southern Caucasus, concretely in Azerbaijan (Bugar Salimov, pers. comm.).

The juice of unripe grapes, known as verjuice in English and agua de agraz in Spanish, has been traditionally consumed in many locations within Spain. Female wild vines produce small bunches with dark-colored berries almost in the totality of the populations, although their flesh is not colored. The maturation of the berries is quite irregular in each bunch, so the resulting must has a rather high acidity, given the high content of malic and tartaric acids (Ocete \& al. 2011b) (Fig. 6). The must also contains sugars, such as glucose, sucrose and levulose, various vitamins, mineral salts, flavonols (quercetin, kaempferol and myricetin) and some anthocyanin pigments from the skin (Velasco \& Lavín 2007). In Arnold (2002) there is an interesting German reference of Bock (1546) pointing out that in the Rhine Basin, the must directly or mixed with milk and sugar, in which case it was called syrupus agrestae, was used for the treatment of epileptic seizures. Some of the aforementioned flavonols seem to act as antiplatelet agents, interesting for the prevention of atherosclerosis and stroke (Ruiz-León \& al. 2019). Lastly, several proteins, vitamis $\left(\mathrm{B}_{1}, \mathrm{~B}_{2}, \mathrm{~B}_{6}\right.$ and $\left.\mathrm{C}\right)$, panthothenic and nicotinic acids, as well as $\mathrm{C}, \mathrm{K}$ and $\mathrm{Na}$, are also present in the must (Pour 2008).

Homemade vinegar production from wild grapes was a fairly widespread practice up to the end of the last century in Sierra Morena mountain-range (Córdoba and Jaén), in Sierra de Cazorla, Segura and Las Villas Natural Park (Jaén) and in Sierra de Cádiz, according to our own observations; also in the Montes de Toledo (Blanco 2002). To produce vinegar, the grapes are laid in the sun and squeezed with the skin in a clay vessel. This derivative from wine has been an outstanding food preservative together with sodium chloride (halite) from the antiquity to present days (Ocete \& al. 2018). 


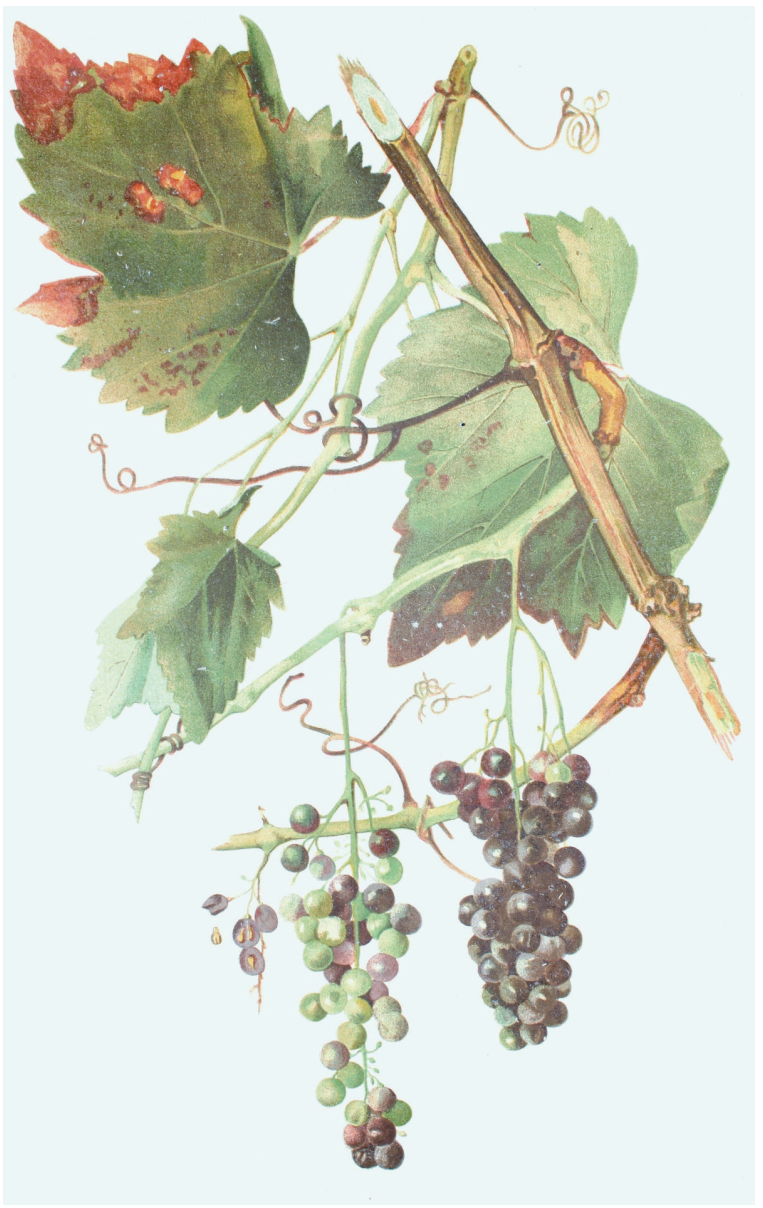

Fig. 3. Illustration of the Virgiliana variety of Vitis vinifera L., taken from Clemente y Rubio (1807).

Up to present time, the only chemical profile of this vinegar was reported by our group. This profile was conducted on a vinegar elaborated with grapes from a population situated along the Iregua river and the national road 111, in La Rioja region (Ocete \& al. 2011a). It has good organoleptic characteristics, according to an expert tasting panel from the Departamento de Nutrición y Bromatología, Faculty of Pharmacy, University of Seville. The concentration of acetic acid was low, $3.5 \mathrm{~g} / 100 \mathrm{ml}$, given the low content of sugar in the berries. The dry extract was around $1.8 \mathrm{~g} / 100 \mathrm{ml}$. The total poliphenol index was about 1200. Color depends mainly on the concentration of monomeric anthocyanins and phenolic compounds, such as gallic and caftaric acids. Volatile compounds were very diverse, with the presence of 42 belonging to different chemical groups. The unique compounds and those that appeared in higher concentrations inside each group were: aldehydes (mainly acetaldehyde), acetals (only acetaldehyde diethylacetal), ethylesters (mainly diethyl succinate), ketones (only aceton), lactones (only butyrolactone), phenols (mainly 4-ethylphenol), acetic esters (mainly isobutylacetate),

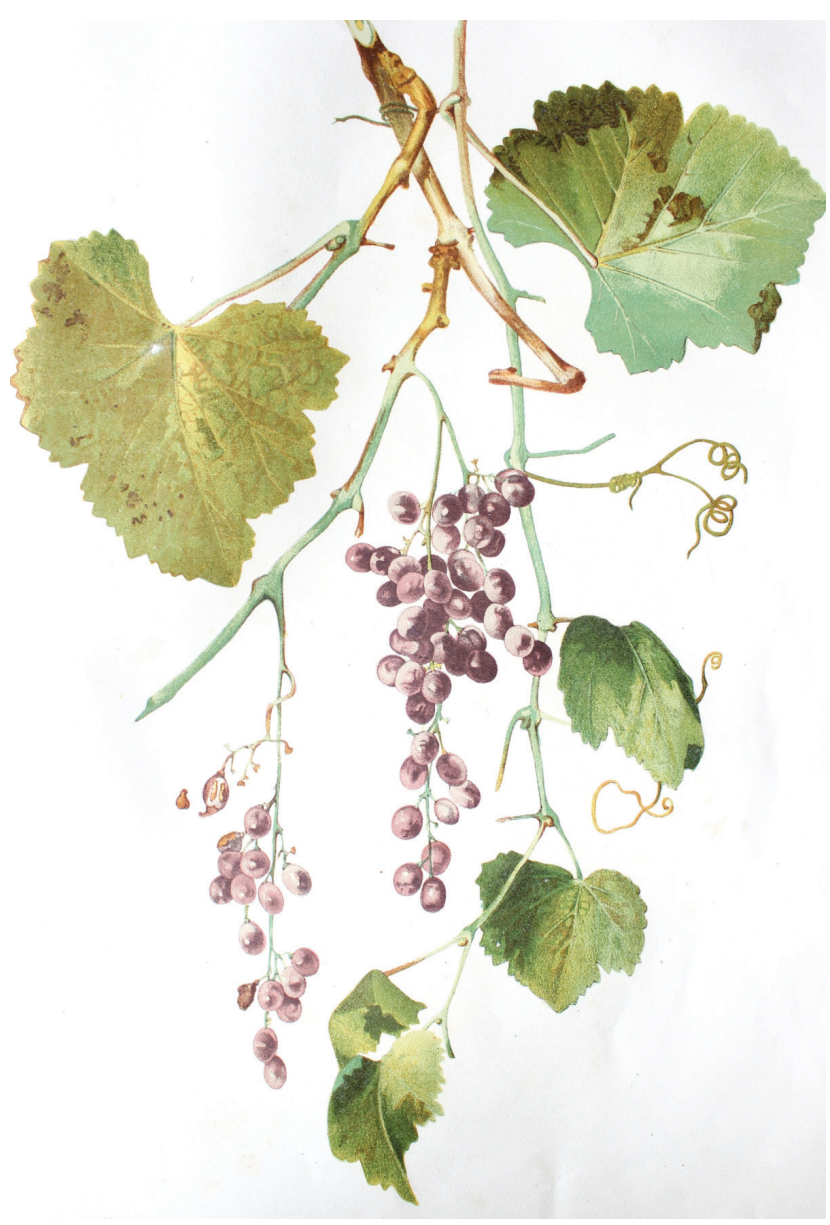

Fig. 4. Illustration of the Garabatona variety of Vitis vinifera L., taken from Clemente y Rubio (1807).

alcohols (ethanol, furfuryl and 1-xexanol) and acids (mainly hexanoic acid).

Besides the fruits, other plant parts from the wild grapevine have been also used. Wild branches, given their great flexibility, were historically used for string manufacturing, such as the strings used by the Spanish Navy (Quer \& Gómez Ortega 1784). Straight stems were used in Montes de Toledo to produce crooks (Blanco 2002). Wild grapevines have also been used in Spain and other countries as natural rootstocks since they are very well adapted to the terrain (Zimmermann 1958; Verde \& al. 1998; Fernández Ocaña 2000; Aceituno-Mata 2010).

The exudates of wild grapevines have been also used. After the fall of the leaves in autumn and the winter rest, when the soil temperature reaches around $10^{\circ} \mathrm{C}$ and other climatic factors are activated, the roots begin to absorb water and nutrients from the soil. This flow of root pressure is directed towards the branches. After a cutting of a branch, the so-called weeping (or bleeding) stage begins (Fig. 7), prior to the development of the 


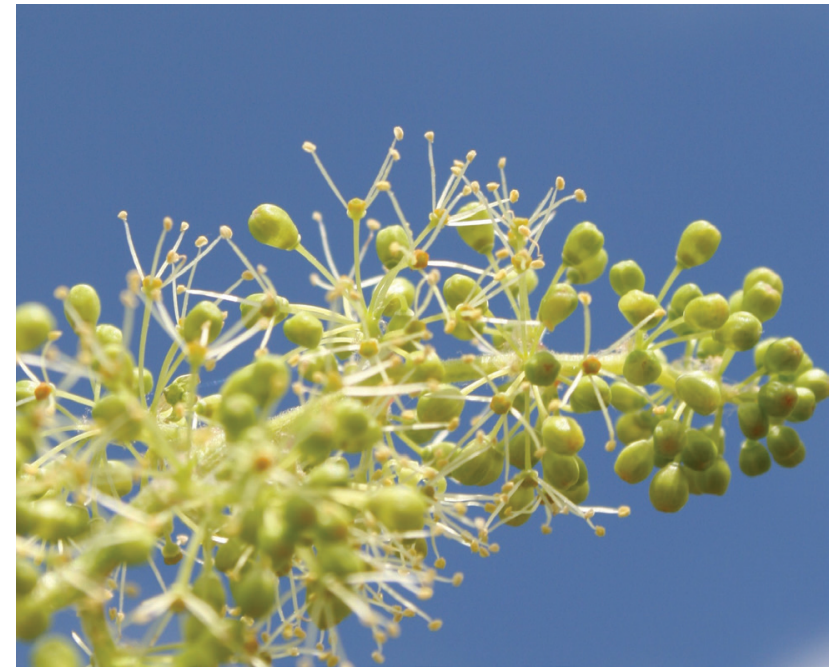

Fig. 5. Part of an inflorescence of a male plant of wild grapevine (Vitis vinifera L. subsp. sylvestris) showing open male flowers and flower buds.

buds (Reynier 1989). According to our observations in natural habitats, this xylem sap exudate is quite copious in the case of wild vines settled in soils with high water availability such as riverside forests or areas with very shallow water tables. During the cutting process, the starch is broken down into lower molecular weight sugars and cellular respiration processes are reactivated. Depending on the location of the vines, the composition of the weeping can vary, as well as its $\mathrm{pH}$. Apart from the aforementioned sugars, the weeping contains amino acids, various cations, such as $\mathrm{Ca}, \mathrm{Fe}, \mathrm{K}$ and $\mathrm{Mg}$, as well as tartaric acid and salts derived from those cations (Hidalgo 2002). The crying is interrupted because colonies of bacteria and fungi begin to develop in the cut areas, plugging the wounds of the xylem vessels (Hidalgo 2002).

Genetic studies indicate that there were several secondary centers of domestication of wild grapevine in the Mediterranean (Arroyo-García \& al. 2006; Cunha \& al. 2010; De Andrés \& al. 2012). Introgression of wild grapevine into close vineyards provoked the development of new varieties in secondary domestication centers (Riaz \& al. 2018; D'Onofrio 2020).

At present time, the wild grapevine constitutes a threatened plant genetic resource, due to human impacts on the wild populations such as the cleaning of riversides, their natural habitat (Ocete \& al. 2007, 2015). There is a great interest to develop new grape cultivars, due to problems derived from drastic genetic erosion in vineyards within the current context of climatic change (Anderson \& Aryal 2017). In the majority of European countries, including Spain, there is a lack of a legal instrument for preservation

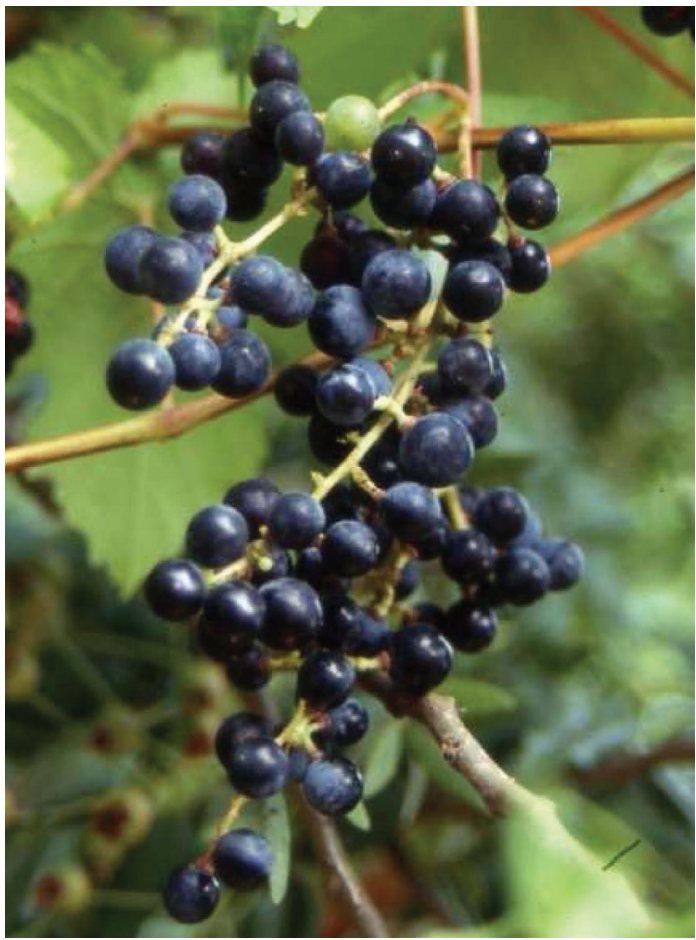

Fig. 6. Ripe bunch of wild grapevine (Vitis vinifera L. subsp. sylvestris).

of the wild grapevine, according to the conclusions of the COST Action 1003 (Viticulture): East-West collaboration for grapevine diversity exploration and mobilization of adaptive traits for breeding (Ocete \& al. 2015). Given this scenario, the aims of this paper were: to record the scattered information about traditional medicinal uses of organs and fluids of the wild grape (Vitis vinifera subsp. sylvestris) in the Iberian Peninsula; to highlight its health benefits; and to promote its biocultural conservation.

\section{MATERIAL AND METHODS}

First, we conducted an exhaustive revision of the Spanish literature from the $16^{\text {th }}$ to $21^{\text {st }}$ centuries on wild grapevine in Spain. Some of the references were included in Ocete \& al. (2011b), a general preliminary paper on the traditional uses of this plant, as fruit food, rootstock, fishing pots, and wine production among others. Second, we carried out an investigation from 1992 to 2020 in several archives in different localities in Spain and Portugal, namely Biblioteca Nacional, Real Jardín Botánico, Universidad de Sevilla, Real Chancillería de Valladolid, Archivo Histórico de Euskadi, Archivo Histórico de Durango, Archivo Histórico de Prado del Rey, Archivo Histórico de Villamartín, Archivo Histórico Provincial de Cádiz, Archivo General de la Casa de Medina Sidonia, Archivo Histórico Provincial de Cáceres, Archivo Histórico de Badajoz, and Archivo General de Extremadura, in Spain, 


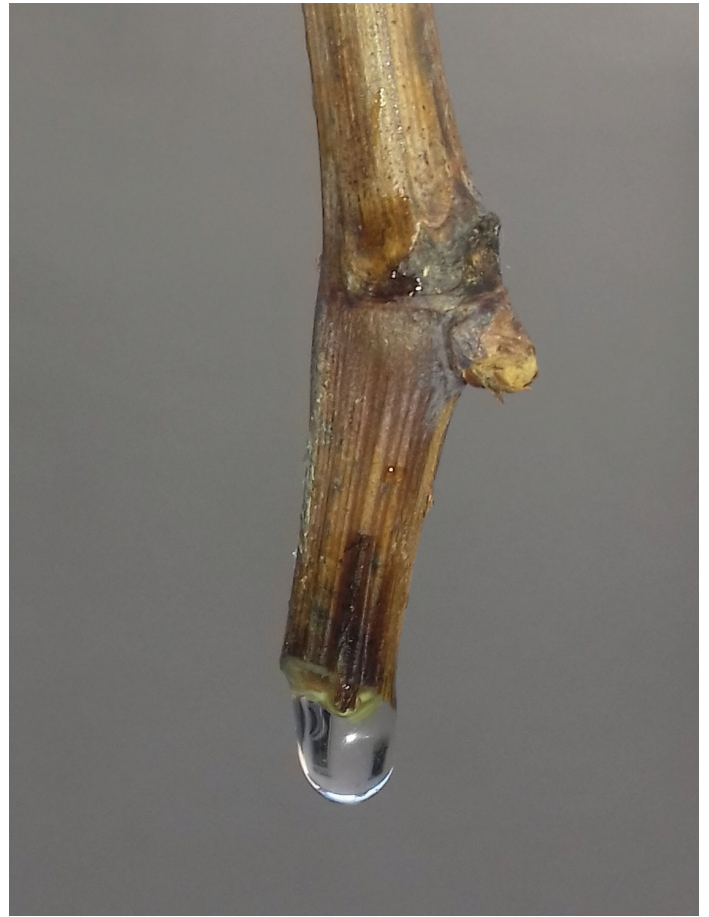

Fig. 7. Cut branch of wild grapevine (Vitis vinifera L. subsp. sylvestris) showing the bleeding water.

and Biblioteca Geral de la Universidad de Évora, Convento de Nossa Segnora da Graça (Évora), Arquivo Histórico de Porto, Universidade Tras os Montes, and Palacio do Conde de Vimioso, in Portugal.

The investigation in archives and libraries was complemented with inquiries to historians, anthropologists and health personnel. Eleven of them are cited as personal communications in the text. Many countryside old people from different regions of Spain and Portugal, where some populations of wild grapevine are still conserved, were also interviewed. The number of people interviewed was 270 in Spain and 186 in Portugal.

Finally, to check if traditional uses have been pharmacologically validated, the most representative chemical components of wild grape products was checked in treaties on pharmacy, medicine, viticulture and oenology.

\section{RESULTS AND DISCUSSION}

The main historical references containing medical applications of wild grapevine are Laguna (1570), Quer \& Gómez Ortega (1784), Font Quer (1961), Bustamante (1971) and Hidalgo (2002). They were completed with Dioscorides ( $1^{\text {st }}$ century) and Bock (1546). Laguna (1570) made a comparison between wild and cultivated grapevines: "Just as the villains and the rustic people differ from those who live in the cities in nothing substantial, only for their very wild customs, for having been raised without discipline, neither does the wild grapevine differ from the domestic vine, not for any other reason, but because this last one was cultivated by the hand and industry of men and that one was born and grew by itself...". He also indicated that the medicinal properties of wild grapevine, except in the case of the must, are superior to those of cultivated grapevines, especially male plants, whose flowers do not develop grapes and were called enanthe by Dioscorides ( $1^{\text {st }}$ century). This Greek medical doctor who served in a Roman legion in Neron's time wrote: “Therapeutic faculties are much more effective in labrusca, and mainly that which produces the enanthe, than in the cultivars."

The locations of traditional pharmacological uses of wild grapevine compiled in the Iberian Peninsula are summarized on a map (Fig. 8). Most of the people interviewed and ethnobotanical Iberian references consulted did not refer any medicinal uses, showing that this knowledge is very limited and that cultural erosion about wild grapevines is very high.

\section{Grapevine bleeding water}

This fluid has aperitif and diuretic actions when ingested. It has been also applied as an eye drop against conjunctivitis and keratitis in people and domestic animals (Sintes 1977). Quer \& Gómez Ortega (1784) reported: "Various medicinal uses are known for both the wild and cultivated grapevines. The water that the vines naturally loose or cry in the spring is aperitif, diuretic and good for the eyes; and for these uses some people keep it".

According to our research, there is memory about the use of this sap against eyes disorders up to 1940-1950 in the Eastern coast of Asturias (along the Cantabrian sea) and around the Matarraña river, near to the Parrizal de Beceite (Teruel, Aragón). It was also used up to the same period along the Asón river basin and in Santoña (Cantabria) and around Montnegre coastal mountain-range, in the Maresme (Barcelona, Catalonia). Here, after the Phylloxera infestation at the end of the $19^{\text {th }}$ century, sometimes the bleeding water was taken not only from real wild vines but also from some other feral Vitaceae, cultivars, and plants of American origin, root-stocks and direct-producer hybrids (French hybrids) (Pep Panon, pers. comm.).

\section{Verjuice or agua de agraz}

Agua de agraz has been used for its toning and liver cleansing properties (Font Quer 1961). In the registry of the Real Chancillería de Valladolid, Castile and Leon, there is a document entitled "Noticia Histórico Corográfica del Muy Noble y Real Valle de Mena", dated 1796, where is written: "Many vines are found in the mountains and on the sides of roads and rivers and their fruits are very good for agua de agraz (verjuice)". 


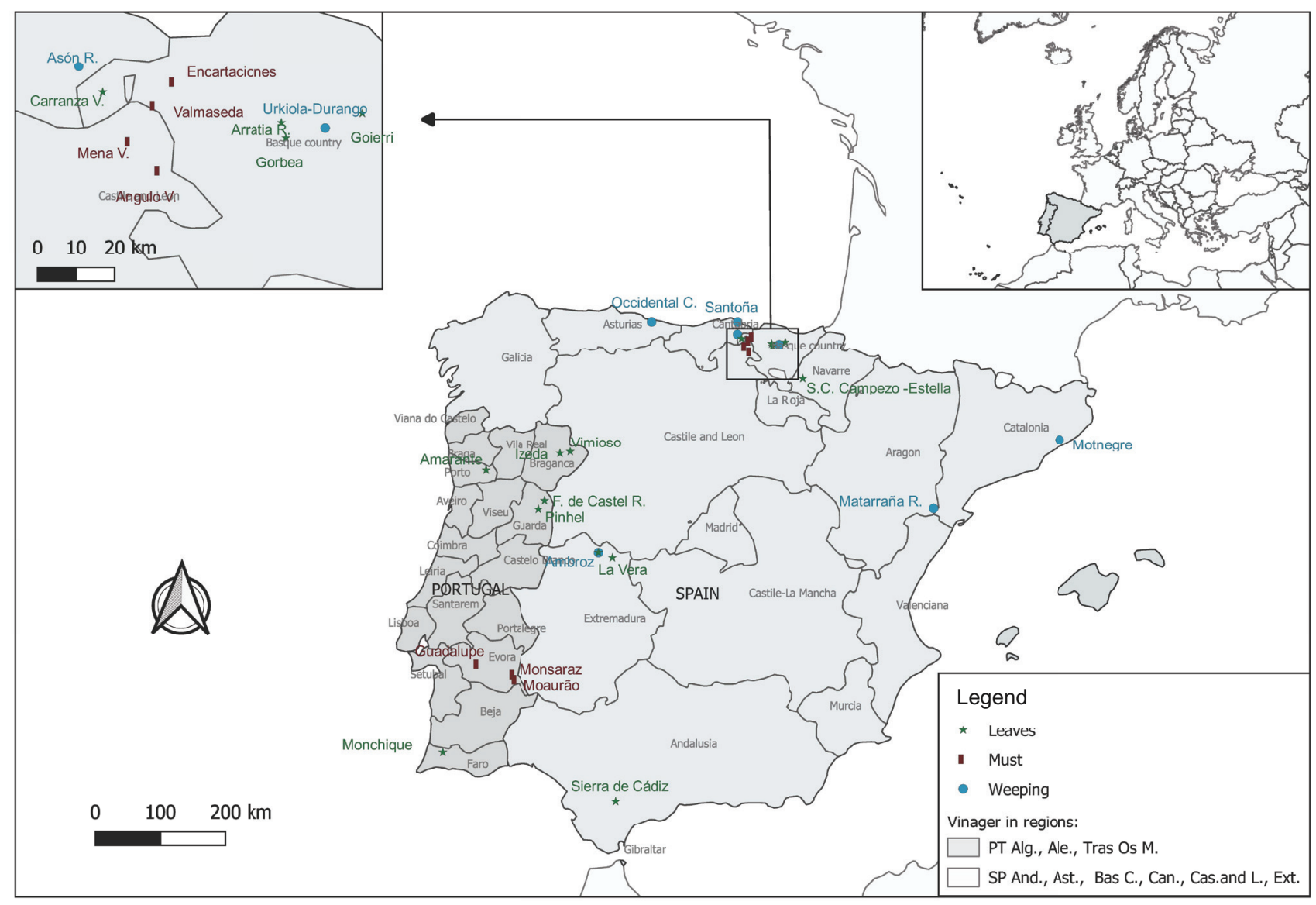

Fig. 8. Location of traditional pharmacological uses of wild grapevine (Vitis vinifera L. subsp. sylvestris) in the Iberian Peninsula.

As indicated by Quer \& Gómez Ortega (1784), verjuice was used to alleviate digestive diseases: "The unripe grapes or 'agraces', and their juice serve to refresh and restrict, excite the appetite, lower the burning of fever, and restrain diarrheal episodes". Pure or with added water, verjuice was used in Mena and Angulo valleys (Burgos, Castile and Leon), up to the end of the decade of 1960 (José Bustamante, pers. comm.). It was also consumed downstream of the Cadagua river in the area of Las Encartaciones (Biscay, Basque country), mainly between the town of Balmaseda and the border with the cited Mena valley. The surroundings of the famous beret factory museum "La Encartada" were visited by the local people to pick wild grapes growing in the forest of the Cadagua river up to 1950-1960 (Javier Otaola, pers. comm.). In Portugal, old people have memory of this use, up to the last cited decade, in Guadalupe, Monsaraz and Mourão (Alentejo region). In the last locality most of the wild grapes collected belonged to the Ribeira das Vinhas population, today submerged under the water of the Alqueva reservoir.

\section{Vinegar}

Wild grape vinegar was used to clean and disinfect wounds in countryside areas of Andalusia, Asturias, Basque country, Cantabria, Castile and Leon, and Extremadura, approximately up to 1950 . The same use is reported in areas of Portugal such as Algarve, Alentejo, and Tras Os Montes up to 1940-1950 (Luis Whyton da Terra, pers. comm.). The vulnerary use for cattle was registered up to the mid-1990s in the Andalusian Sierra de Cádiz (Francisco Guerra, pers. comm.).

\section{Wild grapevine leaves}

Crushed leaves of wild grapevines were used in cataplasms for wounds in the Sierra de Cazorla (Jaén, Andalusia) (Fernández Ocaña 2000), and for wounds and heavy menstruations in the Ambroz river valley and La Vera geographical area (Cáceres, Extremadura), before the Spanish Civil War (1936-1939), where also the dried leaves were ground to be snorted to stop nosebleed (Fernando Forero, pers. comm.). According to our inquiry, the cited cataplasms were also used in Portugal up to 1960 approximately, around the municipalities of Monchique (Algarve region) and along the Sabor river, in the localities of Vimioso and Izeda (Tras os Montes). Similar information and other uses to control diarrhea were reported along the Ega river, from Santa Cruz de Campezo, Álava (Basque country) to Estella (Navarra) (Fernando Andrés, pers. 
comm.) and several isolated farmhouses of other territories in the Basque country, mainly the Goierri area (Guipúzcoa) (José Luis Martínez de Salinas, pers. comm.).

Leaf extract obtained by macerating ground leaves with water was used, up to the last postwar period, to reduce leg swelling in older people in Carranza valley, around the Gorbea mountain and along the Arratia river valley (Biscay, Basque country). It was also used in farmhouses situated around Urkiola and other parts close to the town of Durango in Biscay (Juan Bilbao, pers. comm.). A similar procedure was applied by people in Sierra de Cádiz (Andalusia) to heal the wounds of fighting cocks up to 1960 s.

In Portugal, the cited maceration was used up to 19401950 to alleviate the same human problems in As Beiras region, mainly along the Côa river, around Figueira de Castelo Rodrigo and Pinhel villages. A well-preserved population of wild grapevine, where leaves were collected for that aim, was located in Foz do Rego da Vide, close to rock engravings from the Paleolithic to the Chalcolithic. The same use was practiced in Amarante and Entre Os Ríos in the northern region (Domingos Rocha Mendes, pers. comm.). Boiled water with the leaves is good for the liver and was used in Sierra de Cazorla (Fernández Ocaña 2002).

All these uses of the leaves are consistent with known phytotherapeutical effects of domestic grapevine leaves, especially of the red varieties, which contain tannins with astringent effect, and abundant flavonoids (riboflavin) and anthocyanin pigments, as well as various vitamins (e.g., folic acid), and $\mathrm{Ca}, \mathrm{Cu}, \mathrm{Fe}, \mathrm{Mg}$, and $\mathrm{Mn}$, which give their protective action on blood capillaries and haemostasis (Ortiz 2004; USDA 2013). The grapevine leaves are also a source of nutrients such as vitamins $\mathrm{A}, \mathrm{B}_{6}, \mathrm{C}, \mathrm{E}, \mathrm{K}, \mathrm{Fe}$ iron, fiber, folic acid, as well as $\mathrm{Ca}$, $\mathrm{Cu}, \mathrm{Mg}$, and $\mathrm{Mn}$, as well as substances such as niacin and riboflavin (Bárcena \& al. 2014). According to Ortiz (2004), grapevine leaf extracts reduce edema in patients with chronic venous insufficiency. This is a condition characterized by the difficulty of the veins to return blood from the legs back to the heart (Martínez de Anguiano 1866). When venous blood return is compromised, the increase of hydrostatic pressure into the vessel provokes interstitial edema, resulting in ankle and leg swelling.

According to the information gathered on phytotherapeutical uses in Ortiz (2004) and USDA (2013), crushed leaves of domestic grapevines as well as their extracts (decoction, infusion) have been used in the following cases. 1) Venous circulatory conditions: hemorrhoids, chilblains, varicose veins, tired or swollen legs due to disorders of capillary permeability. It is one of the most active plant remedies against these conditions (Ayuso 2003; Bruneton 2004). 2) Bleeding: especially useful in menopausal disorders, to prevent frequent blood loss; also, in case of hypermenorrhea (too abundant menstruations); as well as to normalize the menstrual cycle in dysmenorrhea (irregular or painful periods). It stops epistaxis (nosebleeds) if it is applied directly, sucking the dust from the crushed dry leaves, in addition to their use in infusion (Ortiz 2004). 3) Gastroenteritis, chronic diarrhea and especially dysentery with bloody stools, due to their astringent and anti-hemorrhagic effect (Ortiz 2004).

In conclusion, the medicinal use of products from the wild grapevine, known since the classical Greek period, has prevailed in isolated rural areas of the Iberian Peninsula until the middle of the last century. However, historical references are very scarce and the knowledge about these uses is currently very diluted due to the abandonment of these uses over the years. Our work highlights the tremendous erosion of the traditional knowledge about this relevant plant. Promoting the in situ and ex situ conservation of this knowledge may help to enhance the social interest in this threatened plant genetic resource.

\section{REFERENCES}

Aceituno-Mata L. 2010. Estudio etnobotánico y agroecológico de la Sierra Norte de Madrid. Tesis doctoral. Universidad Autónoma de Madrid, Madrid.

Anderson K. \& Aryal N.R. 2017. Which winegrape varieties are grown where? A global empirical picture. University of Adelaide Press, Adelaide.

Arnold C. 2002. Ecologie de la vigne sauvage (Vitis vinifera L. ssp. silvestris (Gmelin) Hegi.) dans les forêts alluviales et colluviales d'Europe. Geobotanica Helvetica 76: 1-256.

Arroyo-García R., Ruiz-García L., Bolling L., Ocete R., López M.A., Arnold C., Ergul A., Soÿlemezoglu G., Uzun H.I., Cabello F., Ibáñez J., Aradhya M.K., Atanassov A., Atanassov I., Balint S., Cenis J.L., Costantini L., Gorislavets S., Grando M.S., Klein B.Y., McGovern P.E., Merdinoglu D., Pejic I., Pelsy F., Primikirios N., Risovannaya V., Roubelakis-Angelakis K.A., Snoussi H., Sotiri P., Tamhankar S., This P., Troshin L., Malpica J.M., Lefort F. \& Martinez-Zapater J.M. 2006. Multiple origins of cultivated grapevine (Vitis vinifera L. ssp. sativa) based on chloroplast DNA polymorphisms. Molecular Ecology 15: 3707-3717.

Ayuso M.J. 2003. Vid Roja. In Bravo L. (ed.), Farmacognosia: 328-330, Elsevier, Madrid.

Bárcena L., Beteta Á., Matallana M.C. \& Torija E. 2014. Valor nutritivo de la hoja de Vitis vinifera L. Acta de las XIII Jornadas del Grupo de Horticultura 65: 83-88, Logroño.

Blanco E. 2002. Etnobotánica de los Montes de Toledo. Asociación Cultural Montes de Toledo.

Blanco E. \& Cuadrado C. 2000. Etnobotánica en Extremadura. Estudio de La Calabria y La Siberia extremeñas. Emilio Blanco y CEP Alcoba de los Montes, Madrid.

Bock H. 1546. Kreüter Buch, darin Underscheid, Würckung und Namen der Kreüter so in Deutschen Landen wachsen: auch der selbigen eigentlicher und wolgegründter gebrauch inn der Artznei fleissig dargeben, Leibs Gesundheit zu behalten und zu fürderen seer nutzlich und tröstlich, vorab dem gemeinen einfaltigen Man. Wendel rihel, Strasbourgh.

Bruneton J. 2004. Fitoterapia. Ed. Acribia, Zaragoza.

Burjachs F. \& Julià R. 1994. Abrupt climatic changes during the last glaciation based on pollen analysis of the Abric Romani, Catalonia, Spain. Quaternary Research 42: 308-315. 
Bustamante J. 1971. La tierra y los valles de Mena. Salustegui Editores, Bilbao.

Clemente y Rubio S.R. 1807. Ensayo sobre las variedades de la vid común que vegetan en Andalucía. Imprenta Villalpando, Madrid.

Clemente y Rubio S.R. 1879. Ensayo sobre las variedades de la vid común que vegetan en Andalucía. Imprenta Villalpando. Reedición ilustrada hecha de Real Orden, en honra del autor y en memoria de la primera exposición vinícola Nacional celebrada en España, siendo Ministro de Fomento el excelentísimo señor Conde de Toreno y director General de Agricultura, Industria y Comercio, el excelentísimo señor Don José de Cárdenas. Imprenta Esterotípia Perojo, Madrid.

Chilashvili L. 2004. The vine, wine and Georgians. Authors of the idea. Ed. L. Gachechiladze, T. Kandelaki Tbilisi (in Georgian).

Cunha J., Teixeida Santos M., Veloso M., Cavalcante L., Eiras-Dias J.E. \& Fevereiro P. 2010. The portuguese Vitis vinifera L. germoplasm: genetic relations between wild and cultivated vines. Ciencia e Técnica vitivinícola 21: 25-37.

D'Onofrio C. 2020. Introgression among cultivated and wild grapevine in Tuscany. Frontiers in Plant Science 11: 202.

De Andrés M., Benito A., Pérez-Rivera G., Ocete R., López M.A., Gaforio L., Muñoz G., Cabello F., Martínez Zapater J.M. \& Arroyo-García R. 2012. Genetic diversity of wild grapevine populations in Spain and their genetic relationships with cultivated grapevines. Molecular Ecology 21: 800-816.

Dioscorides ( $1^{\text {st }}$ century $\left.\mathrm{BC}\right)$. Acerca de la materia medicinal $y$ de los venenos mortiferos. Reedition of Vicente Cabrera (1677). Valencia.

Dupré M. 1980. Análisis polínico de sedimentos arqueológicos de la Cueva de les Malladetes (Barx, Valencia). Cuadernos de Geografía 26: $1-2$.

Fernández Ocaña A.M. 2000. Estudio etnobotánico en el Parque Natural de las Sierras de Cazorla, Segura y Las Villas. Investigación química de un grupo de especies interesantes. Tesis doctoral. Universidad de Jaén, Jaén.

Florschütz F., Menéndez-Amor J. \& Wijmstra T.A. 1971 Palynology of a thick Quaternary succession in southern Spain. Palaeogeography, Palaeoclimatology, Palaeoecology 10: 233-264.

Font Quer P. 1961. Plantas medicinales: El Dioscórides renovado. Ed. Labor, Barcelona.

Forni G. 2006. Dall'origine della viticoltura alla sua introduzione in Italia. In Del Zan F., Failla O. \& Scienza A. (eds.), La vite e l'uomo. II Ed. Ersa, Gorizia.

Forni G. 2012. The origin of "Old world" viticulture. In Maghradze D., Rusrioni L., Scienza A., Turok J., Failla O. (eds.), Caucasus and Northern Black Sea Region Ampelography. Vitis 51 (Special Issue): $27-38$.

García-Antón M. 1989. Estudio palinológico de los yacimientos mesopleistocenos de Atapuerca (Burgos): reconstrucción paisajística y paleoclimática. PhD Thesis. Universidad Autónoma de Madrid.

Hidalgo L. 2002. Tratado de viticultura. Ediciones Mundi Prensa, Madrid.

Hopf M. 1961. Pflanzenfunde aus Lerna. Zürcheter 3: 239-247.

Huglin P. 1986. Biologie et écologie de la vigne. Ed. Technique et Documents, Laussanne, Payot et París.

Iriarte-Chiapusso M.J., Muñoz C., Gómez L. \& Ramil, P. 2004. Dinámica del paisaje en la Reserva de la Biosfera de Urdaibai durante el Holoceno. Comunicaciones del III Congreso Español de biogeografía. Isla de Txatxarramendi (Sukarrieta), Reserva de la Biosfera de Urdaibai.
Iriarte-Chiapusso M.J., Salinas J.A., Ocete C.A. \& Ocete, R. 2013. La vid silvestre un taxón amenazado en diversos ecosistemas ibéricos. Cuadernos de la Sociedad Española de Ciencias Forestales 38: $143-148$.

Laguna A. 1570. Pedacio Dioscórides Anazarbeo, a cerca de la materia medicinal y de los venenos mortiferos. Salamanca.

Lehmann J, Böhm G. 2011. Reflexões acerca da presença da Vitis sylvestris na Ibéria durante a era glaciar. In Böhm G. (ed.), Atlas das casta da Península Ibérica: 88-90. Dinalivro, Lisboa.

Logothetis M. 1974. The contribution of the vine and wine to the civilization of Greece and Eastern Mediterranean (in Greek with French summary). Epistemoniki Epetiris tis Geoponikis kai Dasologikis Sholis, University of Thessaloniki 17: 5-286.

Mangafa M. \& Kotsakis K. 1996. A new method for the identification of wild and cultivated charred grape seeds. Journal of Archaeological Scienze 23: 409-418.

Martínez de Anguiano P. 1866. Recopilación histórico-bibliográfica de la circulación de la sangre en el hombre y los animales. Imprenta y Litografía de Agustín Peiró, Zaragoza.

McGovern P.E. 2003. Ancient wine: The search for the origins of viniculture. Princeton University.

Morales R. \& Ocete R. 2015. Vitis (Vitaceae). In Muñoz Garmendia F., Navarro C., Quintanar A. \& Buira A. (eds.), Flora iberica 9: $58-62$.

Ocete R., Arroyo-García R., Morales M.L., Cantos M., Gallardo A., Pérez M.A., Gómez I. \& López M.A. 2011a. Characterization of Vitis vinifera L. subespecies sylvestris (Gmelin) Hegi in the Ebro river basin (Spain). Vitis 50: 11-16.

Ocete R., Cantos M., López M.A., Gallardo A., Pérez M.A., Troncoso A., Lara M., Failla O., Ferragut F.J. \& Liñán J. 2007. Caracterización y conservación del recurso fitogenético vid silvestre en Andalucía. Ed. FALCOR. Consejería de Medio Ambiente, Junta de Andalucía. Sevilla.

Ocete R., Gallardo A., Pérez M.A., Ocete C., Lara M. \& López M.A. 2011b. Usages traditionnels de la vigne sauvage en Espagne. Territoires du vin 03.2011: Les territoires du vin en Espagne.

Ocete R., Fevereiro P. \& Failla O. 2015. Proposal for the wild grapevine (Vitis vinifera L. subsp. sylvestris (Gmelin) Hegi) conservation in the European countries. Vitis 54: 281-282.

Ocete C.A., Martínez Zapater J.M., Ocete R., Lara M., Cantos M., Arroyo R., Morales R., Iriarte-Chapusso M.J., Hidalgo J., Valle J.M., Rodríguez-Miranda A., Lovicu G., Maghradze D., Puig Pujol A. \& Ibañez J. 2018. La vid silvestre euroasiática, un recurso fitogenético amenazado ligado a la historia de la humanidad. Enoviticultura 50: 2-17.

Orrù M., Grillo O., Lovicu G., Venora G. \& Bacchetta G. 2013. Morphological characterisation of Vitis vinifera $\mathrm{L}$. seeds by image analysis and comparison with ar-chaeological remains. Vegetation History and Archaeobotany 22: 231-242.

Ortiz P. 2004. Tratamiento de la insuficiencia venosa crónica. El papel del extracto de hojas de vid rojas. Offarm 23(6): 94-100.

Pour M.S. 2008. General and polyphenolic composition of unripe grape juice (verjus/verjuice) from various producers. Mitteilungen Klosterneuburg 58: 28-31.

Quer J. \& Gómez Ortega C. 1784. Continuación de la Flora Española ó Historia de las plantas de España vol. 5 and 6. Joaquín Ibarra, Impresor de Cámara de S.M, Madrid.

Reynier A. 1989. Manual de viticulture. Ed. J.B. Bailliere, Lavoisier, Paris. 
Riaz S., De Lorenzis G., Velasco D., Koehmstedt A., Maghradze D., Bobokashvili Z., Musayev M., Zdunic G., Laucou V., Walker M.A., Failla O., Preece J.E., Aradhya M. \& Arroyo-García R. 2018. Genetic diversity analisis of cultivated and wild grapevine (Vitis vinifera $\mathrm{L}$.) accessions around the Mediterranean basin and Central Asia. BMC Plant Biology 18: 137.

Rivera D. \& Walker M. J. 1989. A review of paleobotanical findings of early Vitis in the Mediterranean and on the origin of cultivated grape-vines, with special reference to new pointer to prehistoric exploitation in the Western Mediterranean. Review of Paleobotany and Palinology 61: 206-237.

Ruiz-León A.M., Lapuente M., Estruch R. \& Casas R. 2019. Clinical advances in immunonutrition and atherosclerosis: a review. Frontiers in Immunology 10: 837

Sintes J. 1977. Virtudes curativas de la uva. Ed. Sintes, Barcelona.

Stevenson A.C. 1985. Studies in the vegetational history of S.W Spain. II. Palynological investigations at Laguna de las Madres, S.W. Spain. Journal of Biogeography 12: 293-314.

Stummer A. 1911. Zur Urgeschichte der Rebe und des Weinbaues. Mitteilungen der anthropologischen Gesellschaft in Wien 41: 283-296.

Terral J.F., Tabard E., Bouby L., Ivorra S., Pastor T., Figueiral I., Picq S., Chevance J.P., Jung C., Fabre L., Tardy C., Compan M., Bacilieri
R., Lacombe T. \& This P. 2010. Evolution and history of grapevine (Vitis vinifera) under domestication: new morphometric perspectives to understand seed domestication syndrome and reveal origins of ancient European cultivars. Annals of Botany 105: 443-455.

Torres-Vila L.M. \& Mosquera Müller J.L. 2004. Caracterización de las pepitas de vid de una ofrenda funeraria romana bajoimperial (s. IV-V) de Los Bodegones (Mérida). Mérida. Excavaciones arqueológicas, Memoria 7: 455-465.

USDA. 2013. N ${ }^{\circ} 11974$. Grapes leaves raw. Composition of foods raw processed prepared USDA. National nutrient database for standard reference.

Velasco V. \& Lavín A. 2007. Prefactibilidad económica de la produccion de agraz en Chile obtenido de uva cv País (Vitis vinifera L. "Pais"). Agro-Ciencia 23: 17-24.

Verde A., Rivera D. \& Obón C. 1998. Etnobotánica en las Sierras de Segura y Alcaraz: las plantas y el hombre. Instituto de Estudios Albacetenses 102, Albacete

Virgilius ( $1^{\text {st }}$ century BC). Virgilio en verso castellano: Bucólicas, Geórgicas, Eneida. Traducción de Aurelio Espinosa Polit (1961). Ed. Jus, México D.F.

Zimmermann J. 1958. Die Bedeutung der Wildrebe (Vitis silvestris Gmel.) in Jugoslavien für Forschung und Weinbau. Die Weinwissenschaft 8: 79-87. 